Original Research Article

\title{
Analgesic and anti-inflammatory activity of ethanolic extracts of leaf and fruit pulp of Aegle marmelos in albino rats
}

\author{
Krishnakanth K. ${ }^{1 *}$, Abhilash B. G. ${ }^{1}$, Neeraja K. ${ }^{1}$, Hari Jagannadha Rao G. ${ }^{2}$, \\ Chakrapani Cheekavolu ${ }^{3}$
}

${ }^{1}$ Department of Pharmacology, NRI Medical College and Hospital, Chinakakani, Guntur, Andhra Pradesh, India ${ }^{2}$ Department of Pharmacology, ASRAM Medical College

Hospital, Eluru, Andhra

Pradesh, India

${ }^{3}$ Department of Pharmacology, Kerala Medical College Hospital, Mangode, Palakkad, Kerala, India

Received: 05 June 2017

Accepted: 12 June 2017

*Correspondence to:

Dr. Krishnakanth K.,

Email: kkrishnakanth27@ gmail.com

Copyright: (C) the author(s), publisher and licensee Medip Academy. This is an openaccess article distributed under the terms of the Creative Commons Attribution NonCommercial License, which permits unrestricted noncommercial use, distribution, and reproduction in any medium, provided the original work is properly cited.

\begin{abstract}
Background: To study the analgesic and anti-inflammatory activity of the ethanolic extracts of leaf (LE) and fruit pulp (FE) of Aegle marmelos in comparison with the standard drugs pentazocine and diclofenac in albino rats. 56 healthy wistar albino rats of either sex were randomly divided into 14 groups of 4 each $(n=4)$, weighing about 150-200grams were selected for the study. All drugs i.e. $1 \mathrm{ml}$ of $1 \%$ Carboxy methyl cellulose (CMC), pentazocine $10 \mathrm{mg} / \mathrm{kg}$ (intraperitoneal), diclofenac $10 \mathrm{mg} / \mathrm{kg}$ and $\mathrm{LE}$ and $\mathrm{FE}$ at doses of $100 \mathrm{mg} / \mathrm{kg}$ and $200 \mathrm{mg} / \mathrm{kg}$ in $1 \% \mathrm{CMC}$ (vehicle) were administered per oral one hour before the experiment.

Methods: Analgesic activity was assessed by Eddy's hot plate method (latency time) and acetic acid induced writhing (number of writhings) method. Antiinflammatory activity was assessed by carrageenan induced hind paw edema method using digital plethysmometer.

Results: Test drugs at doses LE 200mg/kg and FE 200mg/kg have shown significant increase in mean latency time in Eddy's hot plate $(\mathrm{P}<0.001)$ and decrease in the average number of writhing movements $(\mathrm{P}<0.01)$. LE 200 and FE 200 doses did not show significant anti-inflammatory activity in Carrageenan induced paw edema model $(\mathrm{P}>0.05)$.

Conclusions: Leaf extract (LE) and fruit extract (FE) at doses $200 \mathrm{mg} / \mathrm{kg}$ have shown significant analgesic action and no anti-inflammatory action.
\end{abstract}

Keywords: Analgesic, Anti-inflammatory, Aegle marmelos

\section{INTRODUCTION}

Inflammation and pain are the common problem in many conditions. They are the defense mechanisms to combat the invading pathogen. Inflammation is a protective mechanism triggered in response to noxious stimuli to hasten-up the recovery process. The inflammatory mediators have a role in wound healing, but if it is uncontrolled can act as an etiologic factor for chronic illnesses. ${ }^{1}$ Analgesics are the drugs that selectively relieve pain by acting on the central and peripheral pain mechanisms, without significantly altering consciousness. $^{2}$ The drugs (like opioids, NSAID) currently used for the management of pain and inflammatory conditions, present with many known adverse effects. Moreover, these drugs are very expensive 
to develop, on the contrary, many medicinal herbs have been used as therapy for the relief of pain in the past without any adverse effects. ${ }^{2}$ It is therefore important to have drugs that are safer, cost effective and easily available to rural folks. According to WHO, nearly $80 \%$ of the population in developing countries are dependent on traditional medical practices relying on plant based drugs for their primary health care needs. ${ }^{3}$

Medicinal plants are sources of chemical substances with potential therapeutic effects and literature has documented plants with putative analgesic and antiinflammatory activities. ${ }^{4}$ The documentary evidence for many herbal formulations used for pain and inflammation, related to its safety and efficacy is lacking. To establish the use of herbal medicines in a scientific way with valid evidence, WHO and ICMR are encouraging wide spread researches on herbal drugs. ${ }^{5}$ Aegle marmelos (Bael) is an Indian plant, which has enormous therapeutic value in traditional systems of medicine. It belongs to the family Rutaceae and grows in dry forest, shivaliks and found all over India and Asian countries. The different parts of Bael tree are used for various therapeutic purposes, such as for treatment of fever, arthritis, fractures, healing of wounds, asthma, anaemia, jaundice, diarrhoea, typhoid, hypertension, diabetes mellitus and neurological disorders in traditional systems of medicine. ${ }^{6}$ With this back ground this study has been undertaken to evaluate the analgesic and antiinflammatory activity of the ethanolic extracts of leaf and fruit pulp of Aegle marmelos in albino rats.

\section{METHODS}

\section{Experimental animals}

Wistar albino rats (150-200g) of either sex were randomly divided into 14 groups of 4 rats in each group using computer generated randomization and Institutional Animal Ethical Committee clearance was obtained for carrying out the experiment. Rats were procured from Gentox Bioservices Pvt Ltd, Hyderabad. They were housed in animal room in Air Conditioned atmosphere at an ambient temperature of $25 \pm 1^{\circ} \mathrm{C}$, with alternative lightdark cycle of $12 \mathrm{~h}$ each. They were fed with dry pellets and water adlibitum. Animals were kept fasting overnight and weighed before the experiment. All experiments were conducted between $0900 \mathrm{hrs}$ and $1700 \mathrm{hrs}$.

\section{Preparation of extract ${ }^{7-9}$}

The leaves and unripe fruit of Aegle marmelos (Bael) were washed under tap water, dried under shade and pulverized to coarse powder. The dried powder was separately loaded into the soxhlet apparatus and subjected to extraction for about 36 hours with $95 \%$ ethanol. The extracts obtained separately were filtered, concentrated under reduced pressure on water bath below $50^{\circ} \mathrm{C}$ and dried in rotary vacuum drier to get powder extract. The powder extract obtained was stored in an air tight container kept in refrigerator at $2-8^{\circ} \mathrm{C}$ until further use.

Pentazocine and Diclofenac as Standard drugs for central and peripheral analgesic activity respectively.

\section{Animal experimental groups}

\section{For Eddy's Hot Plate Method (Total 6groups):}

- Group 1, served as negative control, treated with $1 \mathrm{ml}$ of $1 \% \mathrm{CMC}$

- Group 2 treated with pentazocine $(10 \mathrm{mg} / \mathrm{kg}$ ) (IP) as positive control

- Group 3 and 4 treated with Leaf extract (LE) by doses of 100 and $200 \mathrm{mg} / \mathrm{kg}$

- Group 5 and 6 were treated with Fruit extract (FE) by doses of 100 and $200 \mathrm{mg} / \mathrm{kg}$

For Acetic Acid induced writhing (Total 4 groups):

- Group 1, served as negative control, treated with $1 \mathrm{ml}$ of $1 \% \mathrm{CMC}$

- Group 2 treated with diclofenac $(10 \mathrm{mg} / \mathrm{kg})$ as positive control

- Group 3 and 4 treated with Leaf extract (LE) and Fruit extract (FE) by doses of $200 \mathrm{mg} / \mathrm{kg}$ each

For Carrageenan Induced Paw Edema: (Total 4 groups)

- Group 1, served as negative control, treated with $1 \mathrm{ml}$ of $1 \% \mathrm{CMC}$

- Group 2 treated with diclofenac $(10 \mathrm{mg} / \mathrm{kg})$ as positive control

- Group 3 and 4 treated with Leaf extract (LE) and Fruit extract (FE) by doses of $200 \mathrm{mg} / \mathrm{kg}$. each

\section{Study of analgesic activity}

Eddy's Hot Plate Method ${ }^{10,11}$

The hot plate was used to measure reaction time. The animals were placed on electrically preheated surface, temperature maintained at $55 \pm 1{ }^{\circ} \mathrm{C}$. The responses such as jumping, withdrawal of the paws and licking of paws were seen. The reaction time was noted at $0,30,60$ and 90 minutes after administration of drugs respectively. The reaction time was taken as the interval from the instant animal reached the hot plate until the moment animal licked its feet or jumped out. Percentage increase (change) in reaction time ( $\mathrm{I} \%)$, was derived, using the formula: $\mathrm{I} \%=\left\{\left(\mathrm{It}-\mathrm{I}^{\circ}\right) / \mathrm{I}^{\circ}\right\} \times 100$, Where $\mathrm{It}=$ reaction time at time $\mathrm{t}$ and $\mathrm{I}^{\mathrm{o}}=$ reaction time at time 0 hour (basal).

\section{Acetic acid induced writhing ${ }^{12,13}$}

The drugs were administered orally one hour prior to the injection of acetic acid to groups. Writhing in rats was 
later induced by an IP injection of $0.7 \%(\mathrm{v} / \mathrm{v})$ aqueous acetic acid at a dose of $10 \mathrm{ml} / \mathrm{kg}$ body weight. Each rat was then put into a bell jar and the total number of stretching episodes for 20 minutes was recorded after 5 minutes of injection of acetic acid. The number of writhes in each treated group was compared. A reduction in the number of writhes indicates analgesic property. The percentage inhibition (\% analgesic activity) was calculated by: $\%$ inhibition $=\{(\mathrm{A}-\mathrm{B}) / \mathrm{A}\} \mathrm{X} 100$ Where, $\mathrm{A}=$ Average number of writhing of the control group; $\mathrm{B}=$ Average number of writhing of the test group.

\section{Study of anti-inflammatory activity}

\section{Carrageenan induced paw edema ${ }^{14}$}

The drugs were administered orally one hour prior to the injection of $0.1 \mathrm{ml}$ of $1 \%$ carrageenan subcutaneously to the groups. A mark was made at the ankle joint of each rodent. Paw volume was measured at 0,2 and 4 hours respectively after carrageenan injection using digital plethysmometer (INCO Chennai). The mean increases in the paw volume in control and drug treated animals after the carrageenan injection was recorded at 0,2 and 4 hours and percent of inhibition of paw edema was determined using formula. Percent $(\%)$ inhibition $=(1-$ $\mathrm{dt} / \mathrm{dc}) \times 100 \mathrm{dt}$ and $\mathrm{dc}=$ Difference in paw volume in drug treated group and control animals respectively.

\section{RESULTS}

\section{Effect of Aegle marmelos on Eddy's Hot Plate Method}

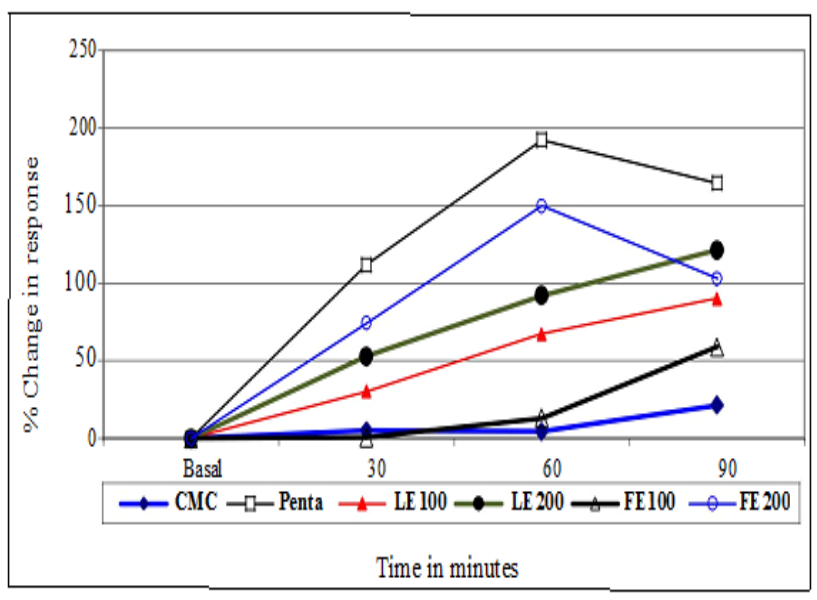

Figure 1: Effect of Aegle Marmelos on hot plate.

Pentazocine (10mg/kg), LE-200 and FE-200 had exhibited analgesic activity by significantly increasing the latency by $30^{\text {th }}$ minute of observation (Figure 1). 2 $>[4 \cong 6] \neq[1 \cong 3 \cong 5]$. By $60^{\text {th }}$ minute of observation, Pentazocine, LE 100 and $200 \mathrm{mg} / \mathrm{kg}$ and FE $200 \mathrm{mg} / \mathrm{kg}$ had exhibited analgesic activity and significantly increased the latency time. However Pentazocine had exhibited more analgesic activity than test drugs. 2 $>[3 \cong 4 \cong 6] \neq[1 \cong 5]$. At $90^{\text {th }}$ minute Pentazocine and LE-
200 had exhibited significant analgesic effect but there was a decline in the action of Pentazocine. LE-100, FE100 and FE-200 did not show significant analgesic effect. The peak onset of action of LE-100 and LE-200 was observed, while there was a decline in that of FE-200 at $90^{\text {th }}$ minute. $[2 \cong 4]>[3 \cong 5 \cong 6] \neq 1$ (Figure 1 ).

\section{Effect of aegle marmelos on acetic acid induced writhing}

Writhing in rats was induced by an IP injection of $0.7 \%$ $(\mathrm{v} / \mathrm{v})$ aqueous acetic acid at a dose of $10 \mathrm{ml} / \mathrm{kg}$ body weight. The number of writhings was counted for a period of 20 minutes. $2>[3 \cong 4] \neq 1$. Diclofenac $(10 \mathrm{mg} / \mathrm{kg}), \mathrm{LE}-200$ and FE-200 have shown significant analgesic effect by reducing the number of writhing movements $(P<0.05)$. The analgesic effect of LE-200 and FE-200 were almost identical to each other which was less than that of the standard drug. The percentage inhibition of writhing movements of various drugs i.e. CMC, Diclofenac, LE-200 and FE-200 were 0, 51\%, $40.5 \%$ and $36.36 \%$ respectively.

Table 1: Effect of Aegle Marmelos on acetic acid induced writhing.

\begin{tabular}{|llll|}
\hline Group & Drug & $\begin{array}{l}\text { Mean } \\
\text { rank }\end{array}$ & $\begin{array}{l}\text { Average number } \\
\text { of writhings }\end{array}$ \\
\hline 1 & CMC & 14.50 & 35.75 \\
\hline 2 & Diclofenac & 3.25 & 17.50 \\
\hline 3 & LE-200 & 7.13 & 21.25 \\
\hline 4 & FE-200 & 9.13 & 22.75 \\
\hline
\end{tabular}

Writhing in rats was induced by an IP injection of $0.7 \%$ $(\mathrm{v} / \mathrm{v})$ aqueous acetic acid at a dose of $10 \mathrm{ml} / \mathrm{kg}$ body weight. The number of writhings was counted for a period of 20 minutes. The discrete data were analyzed by non parametric Kruskal-Wallis one way ANOVA. Diclofenac $(10 \mathrm{mg} / \mathrm{kg})$, LE-200 and FE-200 have shown significant analgesic effect by reducing the number of writhing movements $(\mathrm{P}<0.05)$. The analgesic effect of LE-200 and FE-200 were almost identical to each other which was less than that of the standard drug. The percentage inhibition of writhing movements of various drugs i.e. CMC, diclofenac, LE-200 and FE-200 were 0, $51 \%, 40.5 \%$ and $36.36 \%$ respectively (Table 1 ).

\section{Effect of Aegle marmelos on carrageenan induced paw edema}

The basal paw edema volume of all groups was statistically not significant $(\mathrm{P}>0.05)$. Mean increase in the paw volume was recorded at $0,2 \mathrm{hr}$ and $4 \mathrm{hr}$ using digital plethysmometer. At 2nd hour, only Diclofenac has shown significant anti-inflammatory effect in reducing the paw edema volume ( $\mathrm{P}<0.05)$. CMC, LE-200 and FE200 did not show any anti-inflammatory effect. 2 $>[1 \cong 3 \cong 4]$. At 4 th hour, only Diclofenac has shown significant anti-inflammatory effect in reducing the paw 
edema volume $(\mathrm{P}<0.05)$. CMC, LE-200 and FE-200 did not show any significant anti-inflammatory effect. 2 $>[1 \cong 3 \cong 4]$ (Figure 2 ).

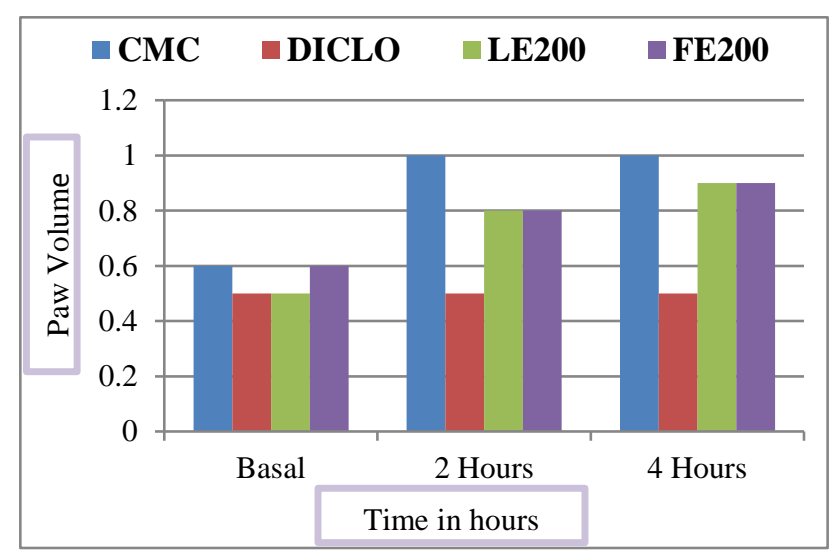

Figure 2: Effect of Aegle marmelos on carrageenan induced rat paw edema (volume).

\section{DISCUSSION}

Aegle marmelos (Bael) is an Indian plant, having enormous therapeutic value. The crude extracts have shown various activities including antipyretic, anxiolytic, antidepressant, antiulcer, antiallergic, antidiabetic, antidyslipidaemic, anti-oxidant, anticancer, radioprotective, antimicrobial, insecticidal, antifungal, antidiarrhoeal, antimicrofilarial, immunomodulatory and antispermatogenic properties. ${ }^{15-27}$ Many biological active phytochemical constituents like coumarins, alkaloids and steroids have been isolated from various parts Leaf and Fruit of Aegle marmelos. Skimmianine, aeglin, rutin, Ysitosterol, $\beta$-sitosterol, flavone, lupeol, cineol, citral, glycoside, halfordiol, marmeline, citronellal, cuminaldehyde phenylethyl cinnamamides, eugenol, marmesinin from leaf Aegeline, marmeline, luvangetin, aurapten, psoralen, marmelide, tannin, pectin, xanthotoxol, imperatorin, riboflavin, vitamin-C from fruit.21,28 In the present study, the analgesic and antiinflammatory activity of ethanolic extract of leaf (LE) and Fruit pulp (FE) of Aegle marmelos was compared with pentazocine and diclofenac. This extract was found to have significant analgesic and no significant antiinflammatory properties. The present study $200 \mathrm{mg} / \mathrm{kg}$ of A. marmelos FE and LE and $100 \mathrm{mg} / \mathrm{kg}$ of $\mathrm{LE}$ extract exhibited significant longer retention time as compared to control $(\mathrm{CMC})(\mathrm{p}<0.001)$, by Eddy's hot plate method, however it was shorter as compared to standard drugs Pentazocine.

\section{Effect of Aegle marmelos on Eddy's hot plate}

The ethanolic leaf and fruit extracts at doses of 200 $\mathrm{mg} / \mathrm{kg}$ have shown significant analgesic activity in hot plate model in rats. The difference in observation might be due to difference in the extract used in the study. Phytochemical constituents of extracts of leaf and fruit pulp are responsible for its analgesic action, which are supported by the earlier study observations and also significant analgesic activity with ethanol leaf extract at a dose of $300 \mathrm{mg} / \mathrm{kg}$ in tail flick latency model in mice. ${ }^{28,29}$ In the present study ethanolic leaf and fruit extracts at doses of $200 \mathrm{mg} / \mathrm{kg}$ have shown significant analgesic activity in hot plate model in rats. The difference in observation might be due to difference in the extract used in this study. Various phytochemical constituents of extracts of leaf and fruit pulp is responsible for its analgesic action, which are supported by the observations of another study. ${ }^{28}$ similar studies are very limited in number, further evaluation of the test drug with more number of animals with varying doses and different screening models are required to support the study. The probable mechanisms for its central analgesic property may be similar to that of opioids which is mainly by increasing the pain threshold and release of endorphins. However the exact compound responsible for this activity is unknown which needs further studies by identification, purification and isolation of individual compounds.

\section{Effect of Aegle marmelos on acetic acid induced writhing}

Acetic acid induced writhing method is one of the most commonly employed procedures for evaluation of peripheral acting analgesic drugs like NSAID's. In the present study both the test drugs have shown significant central and peripheral analgesic activity. But it is not possible to compare and conclude whether the drug has more of central analgesic or peripheral activity because two different screening methods cannot be statistically compared. Based on the percentage change of response in hot plate and writhing models, the drug might be having more of central action rather than peripheral action. These results are similar to that of Gautam et al. ${ }^{30}$ Steroids, alkaloids and coumarins present in the extracts of leaf and fruit pulp might be responsible for the analgesic activity by suppressing the pain due to peritoneal inflammation and significantly inhibiting the number of writhing movements. Further studies are required to conclude the responsible constituent for this action.

\section{Effect of Aegle marmelos on carrageenan induced paw edema}

It is a standard experimental model of acute inflammation. Carrageenan induced paw edema is a biphasic response. The first phase is mediated through the release of histamine, serotonin and kinins, whereas the second phase is related to the release of prostaglandin. ${ }^{31}$ Carrageenan induced paw edema is one of the most commonly employed standard experimental model for the evaluation of anti-inflammatory drugs. It is useful in the evaluation of acute inflammation. In the present study, the results obtained were not in accordance with the above studies, in which the test drugs i.e. Ethanolic extracts LE 200 and FE 200 have not shown any significant anti-inflammatory activity by inhibiting the edema formation when compared to the standard drug 
Diclofenac at $2^{\text {nd }}$ and $4^{\text {th }}$ hour recordings of paw volume respectively. Initially at $2^{\text {nd }}$ hour recording there was inhibition of edema formation compared to the recording at $4^{\text {th }}$ hour which was mean value of 0.8 and 0.9 respectively both being insignificant compared to the standard. It could be because of biphasic response of carrageenan in which the initial phase is due to release of histamine, serotonin and kinins, whereas the second phase is related to the release of prostaglandin. ${ }^{31}$ The probable reasons could be, these extracts at these doses which produced analgesic effect might not be enough to produce significant anti-inflammatory effect and also different extracts and higher doses might have produced the effect. The other reason may be that the readings were recorded for every 2 hours, up to 4 hours only, indicating that further readings should have been measured. Even though the studies done by various authors above have observed significant anti-inflammatory activity, this present study has not shown significant antiinflammatory effect, for the reason could be difference in the dose or the extract used in the study. Moreover, because of its better central analgesic activity than peripheral analgesic activity based on the percentage change response, it might not be having antiinflammatory action.

\section{CONCLUSION}

LE $200 \mathrm{mg} / \mathrm{kg}$ and FE $200 \mathrm{mg} / \mathrm{kg}$ have shown significant dose dependant elevation of reaction time concluding that the test drugs possess central analgesic property. The drugs in the order of their effectiveness was found to be Pentazocine $>$ LE $200 \cong \mathrm{FE} \mathrm{200.} \mathrm{LE} 200 \mathrm{mg} / \mathrm{kg}$ and FE $200 \mathrm{mg} / \mathrm{kg}$ were found to be the effective dose based on the statistical analysis of hot plate time latency results. The drawback of this study is ascertaining the mechanism of action for its analgesic and anti-inflammatory activity is beyond the scope of the present study.

Funding: No funding sources

Conflict of interest: None declared

Ethical approval: The study was approved by the Institutional Ethics Committee

\section{REFERENCES}

1. Muralidhar A, Sudhakar BK, Ravi Sankar T, Reddanna P, Reddy GV, Latha J. Anti-inflammatory activity of flavanoid fraction isolated from the stem bark of Butea monosperma (LAM): A mechanism based study. Int J Phytopharmacol 2010;1(2):124.

2. Pravin VG, Priti SS, Sayyed N, Amol BC. Development and evaluation of analgesic polyherbal formulation containing some indigenous medicinal plants. Int J Pharm and Bio Sci Sep. 2011;2(3):120.

3. Zulfiker AHM, Mahbubur RM, Kamal HM, Hamid $\mathrm{K}$, Mazumder MEH, Sohel RM. In vivo analgesic activity of ethanolic extracts of two medicinal plants - Scoparia dulcis L. and Ficus racemosa Linn. Biol and Med. 2010;2(2):42.
4. Patsnaik AK, Kodati D, Pareta SK, Patra KC, Harwansh RK. Analgesic and anti-inflammatory activities of Buchanania lanzan spreg. Roots. Res J Pharm Biol and Chem Sci. Mar 2011;2(1):420.

5. Aswatha ram HN. Herbal formulations and their standardization. In: Trivedi PC editors. Medicinal plants traditional knowledge. $1^{\text {st }}$ Ed. India: I.K International Pvt Ltd; 2006:1-2.

6. Saroj K, Manish M, Tonpay SD. Anxiolytic and antidepressant activities of methanolic extract of Aegle marmelos leaves in mice. Ind $\mathbf{J}$ Physiol Pharmacol. 2010;54(4):319.

7. Wahid AM, Suyog DM, Suraj BJ, Ajinkya MP, Mukhtar SK, Madhukar RV. Evaluation of antiinflammatory and analgesic activities of ethanolic extract of roots Adathoda vasica linn. Int J Pharm Res. Apr-Jun 2010;2(2):1364-68.

8. Lokesh TN. Analgesic activity of aqueous and alcohol root extracts of Pergularia daemia (forsk) chiov. Int $\mathrm{J}$ Pharm Pharm Sci. Nov-Dec 2009;1(1):33-7.

9. Amberker MV, Tara S, Kumari MK, Bairy KL, Smitha S. Evaluation of anti-inflammatory and analgesic activities of alcoholic extract of Kaempferia galanga in rats. Ind J Physiol Pharmacol. 2011;55(1):13-24.

10. Verma R, Purohit S, Bhandari A, Priyanka P. Analgesic and anti-inflammatory activities of ethyl acetate extract of leaves of Salvadora persica 1. Int $\mathbf{J}$ Pharm Biol Arch. 2010;1(1):51-5.

11. Mayur RB, Yogesh MB, Rohan UW, Umesh TW, Pankaj SS. The analgesic activity of ethanolic extract of tubers of Remusatia vivipara roxb. J Pharmacol Toxicol. 2011;1(6):61-6.

12. Anthony JA, Oluseyi MA, Adeolu AA, Margaret OS. Anti-inflammatory and analgesic activity of the methanol extract of Malva parviflora linn (malvaceae) in rats. Afr $\mathrm{J}$ Biotech. Feb 2010;9(8):1225-29.

13. Sharma A, Bhatia S, Kharya MD, Gajbhiye V, Ganesh N, Namdeo AG, et al. Anti-inflammatory and analgesic activity of different fractions of Boswellia serrata. Int J Phyto. 2010;2:94-9.

14. Raghunadha RS, Rajini P, Koteswararao D, Naidu YK, Chandiran SI, Reddy KMP. Anti-inflammatory and analgesic activity of Smilax chinensis. Res $\mathbf{J}$ Pharm, Biol And Chem Sci. Jun 2010;1(2):1-2.

15. Arul V, Miyazaki S, Dhananjayan R. Studies on the Anti-inflammatory, Anti pyretic and Analgesic properties of the leaves of Aegle marmelos corr. J Ethnopharmacol. 2005;96:159-63.

16. Saroj K, Manish M, Tonpay SD. Anxiolytic and antidepressant activities of methanolic extract of Aegle marmelos leaves in mice. Ind $\mathbf{J}$ Physiol Pharmacol. 2010;54(4):319.

17. Rao ChV, Ojha SKA, Mehrotra S, Pushpangadan P. Analgesic, anti-inflammatory and antiulcerogenic activity of the unripe fruits of Aegle marmelos. Acta Pharm Tur. 2003;45:85-91. 
18. Agung EN, Sugeng R, Mohamad AS, Kazutaka M. Anti-allergic effects of Marmin, a coumarine isolated from Aegle marmelos Correa: In vitro study. Int $\mathbf{J}$ Phytomedicine. 2011;3:84-97.

19. Achyut NK, Rajesh KG, Santosh KS, Sandhya D, Geeta W. Hypoglycemic and antihyperglycemic activity of Aegle marmelos seed extract in normal and diabetic rats. J Ethnopharmacol. 2006;107:37479 .

20. Krushna G, Kareem MA, Devi KL. Antidyslipidaemic effect of Aegle marmelos Linn. Fruit on Isoproterenol induced myocardial injury in rats. The Internet J Pharmacol. 2009;6(2):1-6.

21. Maity P, Hansda D, Bandyopadhyay U, Mishra DK. Biological activities of crude extracts and chemical constituents of Aegle marmelos corr. Ind J Exp Bio. 2009;47:849-61.

22. Rajesh K, Ashok K, Chandra Shekhar P. Insecticidal activity of Aegle marmelos (L.) Correa essential oil against four stored grain insect pests. Internet J Food Safety. 2008;10:39-49.

23. Rana BK, Singh UP, Taneja V. Antifungal activity and kinetics of inhibition by essential oil isolated from leaves of Aegle marmelos. J Ethnopharmacol. Elsevier. 1997;57:29-34.

24. Meshram M, Ravikanth K, Maini S, Rekhe DS Treatment of clinical cases of Bacterial enteritis in Goat with new polyherbal antidiarrhoeal formulation. Veterniary World. Apr 2009;2(4):143-5.

25. Lambole VB, Krishna Murti, Upendra K, Bhatt SKP, Gajera V. Phytopharmacological properties of Aegle marmelos as a potential medicinal tree. Int J Pharm Sci Rev and Res. 2010;5(2):67-72.
26. Ankur C, Aadarsh C, Asish M, Shilpi M, Patil UK. Evaluation of the Immunomodulatory activity of methanolic and ethanolic extract of leaves of Aegle marmelos in rats. Int $\mathbf{J}$ Drug Dev and Res. Jul-Sep 2010;2(3):664-8.

27. Alka C, Meera A, Sonalika K, Anju M. Suppression of fertility in male albino rats following the administration of $50 \%$ ethanolic extract of Aegle marmelos. Contraception. 2007;76:474-81.

28. Rishabha M, Kumar A, Singh A, Kulkarni GT. Pharmacological screening, ayurvedic values and commercial utility of Aegle marmelos. Int J Drug Dev Res. Jan-Mar 2012;4(1):28-37.

29. Shankarnanth V, Balakrishnan N, Suresh D, Sureshpandian G, Edwin E, Sheeja E. Analgesic activity of methanol extract of Aegle marmelos leaves. Biological Trace Element Research. 2007;78:258-59.

30. Gautam MK, Ghatule RR, Singh A, Purohit V, Gangwar M. Ind J Exp Biol. Feb 2013;51:157-64.

31. Neto AG, Costa JMLC, Belati CC. Analgesic and anti-inflammatory activity of crude root extract of Pfaffia glomerata (Spreng) Pedersen. J Ethnopharmacol. 2005;96:87-91.

Cite this article as: Krishnakanth $\mathrm{K}$, Abhilash $\mathrm{BG}$, Neeraja K, Rao HJG, Cheekavolu C. Analgesic and anti-inflammatory activity of ethanolic extracts of leaf and fruit pulp of Aegle marmelos in albino rats. Int J Basic Clin Pharmacol 2017;6:1596-601. 